\title{
CORE TOPICS OF VISUAL CULTURE STUDIES AND UTILIZING SEMIOTIC METHOD
}

\author{
Bengü BATU ${ }^{1}$
}

\begin{abstract}
Visual culture is being forged and becoming more widespread due to imaging technologies. It is instrumental in imposing the ideologies of dominant authoritative structures on individuals. Visual culture has also begun to influence and transform the qualitative foundations of aesthetic perception. These developments were also have an impact on art education. Recent years have seen an increase in studies relating to visual culture in the field of art education. In the field of criticism, the quantitative increase in semiotic studies is especially noteworthy. The semiotic approach deals with meaning, signification and the manufacture of meaning. It is thought that the analytical methods proposed by semiotics might be more effective in the criticism of visual culture in art education. The study will seek to answer: What is visual culture? What is semiotics? What are the core topics of visual culture studies and utilizing semiotic method on them in art education? The study will employ descriptive analysis - a qualitative research method. The study indicates that research made on visual culture concentrates on ideology and power, representation, attraction, perception, intertextuality and polymorphism which can also be studied using semiotic method.
\end{abstract}

Keywords: Art education, visual culture, semiotic method, art criticism, fine arts.

1 Yrd. Doç. Dr., Bülent Ecevit Üniversitesi, Güzel Sanatlar Fakültesi/ Resim Bölümü, bengubatu2(at)hotmail.com 


\title{
GÖRSEL KÜLTÜR ÇALIŞMALARININ ANA KONULARI VE BUNLARIN ÜZERINDE GÖSTERGEBILIMSEL YÖNTEMIN KULLANILMASI
}

\begin{abstract}
ÖZET
Teknolojik görüntüleme araçlarının hızlı gelişimiyle birlikte görsel kültür oluşarak, yaygınlaşmakta ve hakim olan egemen güçlerin (kapitalizm) ideolojilerini bireylere dayatmaktadır. Görsel kültür, estetik anlayışın niteliksel temellerini de etkilemeye, dönüştürmeye başlamıştır. Görsel kültürün bir parçası olan sanatın görsel kültürle dilsel ve göstergesel bir alışveriş içine girmesi sanat eğitimini de etkilemektedir. Son yıllarda sanat eğitimi alanında görsel kültür ve göstergebilimle ilgili araştırmaların nicel artışı dikkat çekmektedir. Göstergebilim anlamla, anlamın üretim süreci ve eklemleniş biçimiyle ilgilenen bir etkinliktir. Mantık temelli bir yöntem olan göstergebilimsel yaklaşımların sanat eğitiminde görsel kültür ürünlerinin eleştirisinde daha etkili bir şekilde kullanılabileceği düşünülmektedir. Araştırmada 'Görsel kültür nedir? 'Göstergebilim nedir?' 'Görsel kültür çalışmalarının üzerinde durduğu ana konular nelerdir ve sanat eğitiminde bunların üzerinde gösterge bilimsel yöntem nasıl kullanılır?' soruları araştırılmıştır. Bu çalışmada nitel araştırma yöntemlerinden betimsel çözümleme yöntemi kullanılmıştır. Görsel kültür çalışmalarının ideoloji, güç, temsil, alg1, metinlerarasılık ve polimorfizm konularına odaklandığı tespit edilmiştir. Tüm bu konuların da göstergebilimsel yöntemle çalışılabileceği belirlenmiştir.
\end{abstract}

Anahtar Kelimeler: Sanat eğitimi, görsel kültür, göstergebilim, sanat eleştirisi, güzel sanatlar

Batu, Bengü."Core Topics of Visual Culture Studies and Utilizing Semiotics Method". idil 5.21 (2016): 297-312.

Batu, B. (2016). Core Topics of Visual Culture Studies and Utilizing Semiotics Method. idil, 5 (21), s.297-312. 


\section{INTRODUCTION}

As visual culture becomes established through imaging technologies, it also becomes more widespread and gains a foothold in the general global culture. In his commentary in the 1960's, Debord defined modern society as a society of viewers that consumed images, visuals and spectacles that were removed from real life (Trier, 2007: 68-73). Likewise, Barnard argued that our culture was gradually becoming a product of our viewership (Barnard, 2010: 13). Actions perpetrated by people to transform nature and imbue their existence with meaning, along with the resulting information and products, comprise culture as a whole. Currently, such information, actions and products are observed to be tech-based. These technologies bring with them the ethos and social relationships of the current age in addition to the preconceptions of the dominant ideologies (such as capitalism). In this period, deemed "late capitalism" by Jameson, the perception, learning and knowing processes of humanity started to be determined by visual culture to a large extent (Jameson, 1994). Postmodernism comes to the fore as the cultural framework of this occurrence. Its distinct element is that it expresses a new period, and it takes a critical stance against basic theses and agreements of modernity. Parameters determining postmodernity are media using advanced technology, visual culture and the consequent transformation arising in societal relationships. Thus, technologies and their output are also ideological tools used in the shaping of culture. As they act on and shape culture, technologies and their visual by products also concoct a fallacy. Technologies with imaging capability are seen as the documenters of truth and, as such, their visual output is paraded as the truth (Aslan, 2003: 39-64). Power is exercised over individuals by engineering the relationships between subjects that are able to perceive and acquire knowledge and by the scientific administration of imagery (Artun, 2011).

By incapacitating the critical faculties of society, the dominant ideology (capitalism) is able to perpetuate the system that it has put in place. Messages and the values of the dominant ideology that are propagated through visual culture distort other existing cultures, gradually making them more similar to the mainstream. When mainstream culture is mentioned, this usually refers to western culture. As the media combines the visually propagated popular culture with mass culture, this also has an impact on art. Visual culture and the tools at its disposal, as the source of cultural creation, begin to impact and transform the qualitative foundations of aesthetic sensibility. Danto argues that our current definition of art is readily accepting of all works as art. This period began with pop art, a branch of the arts that drew on visual culture for the first time (Danto, 1997). Greenbergian critique could no longer distinguish between reality and works of art. Greenberg held that the trained eye 
would be capable of separating an accomplished work of art from a dud. Either way, the eye could do very little to distinguish Warhol's Brillo packaging from anything else. This marks the end Kant's aesthetic, which was based on gratification. These developments were also to have an impact on art education and art criticism. Art criticism shifted its focus from the subject of the artwork to what it represented (Danto, 1997). There has always been a strand of symbolism and symbolic thinking in visual arts. Beginning from the earliest periods in history, people have attempted to extract their feelings, thoughts and testimonies from their minds and transfer them onto any surface and form (ideogram, pictogram, painting, etc.) Signs are essential to the make-up of all branches of art. In a work of art, we set off from the reality perceived with senses and discover meaning. Art, a visual sign, has a tangible aspect perceived with senses, as well as the aspect shown by this sign (signified). This conceptual aspect is always connected to language. When we look at history of art, we see that the history of arts is a history of representation. Depending on historical conditions, representation in art shows up in various ways. Sometimes it has been direct, sometimes indirect and symbolical, and sometimes abstract and conceptual. As a means of representation, works of art is a sign of their respective period and society, even if a relative one, and also a projection of that period and society. They are visual transformation and transferors of a certain consciousness of the world. From this aspect, art has always been connected to symbolical thought. On the other hand, in postmodern sense of art, forms of representation became unlimited in terms of material, technique, presentation and exhibition opportunities, and an interdisciplinary approach became predominant. Traditional sense of aesthetic gave way to inquisitions about language and meaning. Meaning and textual contents here fore of the artistic production. Contemporary art practice embodies many elements from everyday life, and thus also from visual culture, as the art aesthetic, too. It is crucial for art students in particular to question the mass visual culture, popularized through technological means, and the values and messages the system imposes on us. It is thought that the analytical methods proposed by semiotics might be more effective kin the criticism of visual culture in art education. Indeed, the field of visual culture is pedagogy of the image and concerns itself with how we see things, how we assign meaning to them, and what significance artificial images have for the individual, society and the world at large. The semiotic approach deals with meaning, signification and the manufacture of meaning. It is here that semiotics may be of use to us in our study of visual culture as part of the art education process by helping us uncover the meaning of messages that are transmitted to us and which blunt our critical faculties. Through the use of descriptive analysis, this study will attempt to answer such critical questions as, 'what is culture?', 'what is semiotics?', and 'What are the core topics of visual culture studies and utilizing semiotic method on them in art education?' 


\section{What is Visual Culture?}

A mass culture is being created where visual experiences are the dominant force. This mass culture is referred to as 'visual culture'. When attempting to define visual culture, Barnard began his research by addressing the two concepts, i.e., visual and culture, separately. He defined the visual as "everything visual produced, interpreted or constructed by people that aim to be functional, communicative and/or aesthetic' (Barnard, 1998: 34). Visual culture is the visualization, through various means, of the values and beliefs of a culture. Culture is the interaction of a series of tangible, substantive elements and abstract ones such as values, beliefs and social norms (Sezal, 2002). Culture is the result of human beings theorizing about their existence, transforming nature in order to assert themselves and creating products and signs. Altering nature and giving meaning to one's existence is only possible through the knowledge and tools mankind has developed for this purpose. Current technologies have become indispensable to culture - massively popular visual culture in particular - and the art which is borne out of it. On the other hand, the means of production and materials of art and visual culture and the indicators occasionally employed by them have begun to collaborate. One can ask what are the differences between works of art that are a part of visual culture and also enter a linguistic and semiotic interchange with visual culture, and products of visual culture. Visual culture encompasses a very wide range of products, from architectural designs, to ads, films, computer games, webpages, newspapers and magazines. We can say that in terms of the current state of today's art, this distinction is determined by context and institution, and in terms of the products, it is determined by choices of the artist, the method of production and transfer, and limits of meaning and connotation. Art which constitutes an important aspect of visual culture not only contribute it but is also influenced by the visual culture aesthetic. Today, a contemporary art practice embodies many elements from everyday life, thus also from visual culture, as the art aesthetic, too.

Simply defining what visual culture is cannot be sufficient enough to understand it. It is also necessary to specify the study methods used in visual culture research and explain what they are. Visual cultural studies involve the examination of the social and cultural aspects of visual experiences. These studies not only examine the messages, meaning and criticism of the visual, but they also focus on how a different visual might be produced (Aslan, 2003:39-64). In its essence, the research employs a critical approach. The analytical and critical approach used in visual cultural studies may be built on the meaning of objects that are visible, invisible or knowingly concealed (Rogoff, 1998). What is created or produced or formed under different conditions may be subject to examination. Visual imagery and indicators are 
evaluated based on their economic and political contexts. The political relevance of visual representations is scrutinized. Visual cultural studies lays out the meanings inherent in a painting, an advert, a television programme, a photograph or a film. In addition, it is also concerned with the role of gaze and perception, together with its social basis, and the relationship between the audience and the observed object (Duncum, 2003: 19-25). Topics being studied in visual culture range from the auditory, the spatial and the analysing of the visual to its interpretation and the spiritual dynamics of the viewing experience. What we see, the meanings we derive, common meanings constructed by different social classes, how we see and think, what the temporal and contextual forces influencing our views and thoughts are, what we cannot perceive or are restricted from seeing are all within the purview of research on visual culture. And it isn't just the visual itself that is the primary concern of visual cultural studies; it is also the meanings the visual creates in the eyes of society and the world in general. The way in which different classes and groups interpret and consume visual culture may vary. Time and context may alter the meaning of consuming visual culture. These variations are also of interest to visual cultural studies. Central to the problems surrounding the visual in visual cultural studies are interdisciplinary methods - which span all disciplines. However, the fact that the main areas of visual cultural study involve meaning and the creation of meaning, may result in analytical methods focused on meaning to become central to these studies. As the definition suggests, visual culture is mainly comprised of visual indicators. The meanings that all these indicators transmit are related to semiotics. That is why it is necessary to touch upon what constitutes the semiotic method - one which, it is assumed, can be effectively used in visual cultural studies.

\section{What is Semiotics?}

The emergence of semiotics dates back to the beginning of the $20^{\text {th }}$ century. Saussure and Pierce were instrumental in its recognition as a branch of the social sciences. Commenting on semiotics as a prospective field of study, Saussure, in his book, Lectures on Linguistics, argued that communication was based on a system of indicators and that many systems had to be studied within the realm of semiotics. Pierce saw semiotics as a field that was applicable to and necessary for all sciences and areas of study (Akerson, 2005). Semiotics is a branch of study that takes its cue from theories on linguistics. It embodies many different theoretical approaches and varied practices. There are a variety of linguistic and semiotic approaches that originate from different environments and schools. Some of these schools include; Geneva School of Linguistics, Prague School, Copenhagen School of Linguistics, Functional Linguistics School of France, Paris School of Semiology. In explaining semiotics, we can only formulate a definition by touching on the general commonalities between these approaches. Indeed, the body of work concerned is far 
wider in scope than the length of this article will allow. Before providing a generalized definition of semiotics, it is necessary to give some background on the term 'sign'. A sign may be defined as any construction, object, action, etc. that is representative of something other than itself and can therefore be substituted for the thing being represented. They are a system of whole, eclectic units used by people to negotiate and communicate and may or may not be intended for exchanging information. Units found in such systems, whose plane of occurrence and characteristics differ, are known as 'signs'(Rifat and Rifat 2000). All signs are comprised of a signifier and a signified. The meaning materializes due to the correlation between the signifier (form) and the signified (concept). Each sign is an external sensory symbol coupled with the reality and meaning it represents (Tunal, 2004). A sign attains more pronounced meaning and value within a context. Signs are essential to the makeup of natural languages, images, words, symbols, the entire output of the media of visual culture, written texts, products of all branches of art. They fall within the scope of semiotics. Semiotics embodies an aspect that extends beyond its etymology, i.e., a word combining 'signs' and 'science'. In addition to the scientific study of signs it also concerns itself with meaning, meaning-making and the process of manufacturing and extending meaning. Its object is to analyse the different layers of meaning present in a given whole, no matter what form it takes, and to reintroduce them by means of a meta-language and a series of methods and processes. Its purpose is to conduct a controlled and objective examination that is based in logic. The structure assumed to be present in the object under scrutiny is systematically separated, analysed and reconfigured using a meta-language. Hence, semiotic analysis is gradually able to determine meaning, how meaning is produced and extended, the plane meanings transmitted by signs, ancillary meanings, basic meanings and intertextual relationships. The object under examination can be analysed gradually, from the surface to its deep recesses, by separating it into its component layers. Conversely, the examination can start deep and progress towards the surface. From this point of view, it becomes clear that the methods suggested by semiotics can be used effectively in visual culture research. The messages and meanings transmitted to us by the visual culture may also be uncovered systematically using the methods of semiotics.

\section{Core Topics of Visual Culture Studies and Utilizing Semiotic Method}

The visual culture and the means that have propagated it have transformed art products, production processes and their aesthetic references, all of which constitute an important part of visual culture. UNESCO, having foreseen the potentially damaging influence of the emerging mass culture, issued a statement in 1982: 
The school and the family share the responsibility of preparing the young person for living in a world of powerful images, words, and sounds. Children and adults need to be literate in all three of these symbolic systems, and this will require some reassessment of educational priorities (Thoman, 2008: 11).

Research shows indicates that today's youth is informed differently owing to the influence of digital media such as the internet, computers and mobile phones (Prensky, 2001: 1-6). Art students and young individuals who actively use visual culture and the devices that produce it while growing up are impacted cognitively and emotionally. In addition, art, which constitutes an important aspect of visual culture, not only contributes to it, but is also influenced by the visual cultural aesthetic. Artists' use of visual cultural media in their creative processes can also blur the lines between what is art and what is not. We are now at a point where we cannot think of the concept of art as separate from visual culture due to these disappearing boundaries between products of visual culture and art. In the field of art education there is a need to assess the impact and provide a critical outlook of visual cultural products. This has also served to highlight the question of how visual culture should be analysed and critiqued. As critical intent appears to be central to the analyses of visual culture, this leads one to believe that it may be possible for visual cultural analyses to play a partial role in criticism and courses related to criticism in discipline based art education. In art education, critical and visual literacy must be developed in order to determine the differences between the various forms of visual culture and the messages they contain. Critically analysing visual imagery and symbols during the visually literate process requires three fundamental tasks. Visual images must be correctly placed into their social and political contexts. Meaning and their areas of influence must be pinpointed. It is necessary to uncover and critique images and signs that encourage otherness and discrimination (Kellner, 2002: 81-90). These three fundamental tasks also appear to be related to uncovering the meaning underlying visual images and signs. The process of visual literacy is not limited to a single method. Interdisciplinary methods are thought to be more beneficial in interpretations of visual culture in art education. In the analysis of visual culture, revealing the meanings transmitted by the object under scrutiny appears to be central. In visual culture, the emphasis is on the meaning the image conveys to the individual, society and the world, rather than the image itself.

Research shows that the study of visual culture centres on specific topics. These include ideology-power, representation, perception, intertextuality and polymorphism (Mirzoeff 2002, Duncum 2010, Tavin 2009, Rogoff 1998). Topics that concern visual cultural studies are also within scope of semiotics. Visual cultural 
studies' remit is to uncover and critique the messages, meanings and ideologies inherent in the images transmitted through visual culture. The semiotic method may be effectively employed in analysing the images, that is to say the transmitted meanings and ideologies, which make up visual culture, because the ideologies that are potentially present are revealed when the object under scrutiny is analysed by means of the semiotic method. This aspect of the semiotic method is especially conducive to the objectives of studies on visual culture. The manifest language, the level of discourse and narrative, and the deep meaning of the object being analysed via the semiotic method is gradually and systematically exposed. The first step is to interpret the level of the manifest language. Then, the focus can shift to the level of discourse. The individual and the temporal and spatial elements populating the object under examination are identified and the themes can thus be understood. At the narrative level, the functional narrative units are determined. The relationships between them are composed in an arrangement. During the semiotic analysis, when the narrative programme is being disclosed, efforts are made to identify the process whereby the performance statement influences a condition statement, resulting in it being transformed into a unique condition statement (Rifat, 1992). When a performance statement influences and alters a condition statement, this has to do with 'power'. The concept of power is one of the central aspects of visual cultural studies, because the images that comprise visual culture cannot be considered separately from those who wield power. The messages that the ruling class intends to disseminate through the visual cultural means at its disposal are bound together with their ideology. When conducting visual cultural studies, meanings associated with culture and ideology that potentially exist at the deep meaning level of the examined object can be identified using the semiotic method. The French semiotician, Gerimas, held that all cultural objects grappled with life on a deep structural plane. According to Greimas, the existential social problems and ideologies of man were the building blocks of this deep structure (Akerson, 2005: 148). In addition Voloshinov's ideas were extremely significant in emphasizing the relationship between images and ideology. According to Voloshinov, ideologies cannot be uncoupled from the material realities of signs. The ideologies and values transmitted at the deep meaning level inherent in all manner of visual cultural objects may be accessed using semiotic methods (Mumby, 1989: 291-304).

Another issue arising as a core topic in visual culture is representation. All things substitutable for other things that can invoke, in the human mind, the thing being supplanted are defined as representations. If a representation refers to itself, it is an object; if it is representative of something else, it is a sign. Representations define the planes of the signifier and the signified. The signifier is associated with form, whereas the signified relates to meaning. Representations that transmit meaning 
invariably include the construct of reality. That representations embody the construct of reality is a phenomenon that falls within the scope of visual cultural studies, because representations - when they are signs - are constructed and composed to serve a certain function inside a specific sociocultural environment (Leppert, 2009). Power is exercised over subjects by designing and scientifically overseeing the relationships between subjects that see and understand the world through representations. Therefore, the object of visual cultural studies is the identification and critique of meanings and ideologies transmitted by such representations.

Visual transmissions include connotative meanings in addition to meanings that are readily manifest. Founder of the Copenhagen Linguistic Circle, Hjelmslev, defines manifest meaning and connotative meaning as opposing planes of the same sign. Every sign may carry meanings that are additional to the initial meaning (the manifest meaning) (Rifat, 2008). The connotative meaning of the sign relates to the emotions and cultural values of those who encounter and make use of it. This is related to the gaze; a topic that visual cultural studies is concerned with. The connotative meaning of the sign may vary and become enriched depending on the viewer, the gaze and the culture and sociocultural class giving it direction. Interpreting the connotative meaning transmitted by the signs of visual culture requires learning to read them - in the way one does with language. By employing the semiotic method in visual cultural studies, it is possible to determine which manifest and connotative meanings are transmitted by the signifier plane of the said representations and which ideologies potentially present themselves in their deep meaning.

Intertextuality is a discursive space that was important to artists, semiologists, and visual culture researchers after the 1960's. Intertextuality was researched by several linguists and semiologists, including Kristeva, Barthes, Riffaterre and Genette. According to Kristeva, intertextuality is the act of creating a novel sign system by imbuing multiple sign systems with new meaning. Intertextuality should be understood as a method of exchange between two or more texts (Alfaro, 1996). Post1960 's artworks point to a proliferation of artists who made connections between texts by borrowing from the images and signs transmitted by the media and the design world. These artists chose to use as a resource the output of visual culture and things that were already produced rather than what was available in nature. In addition, every kind of visual cultural product was observed borrowing, in various ways, from the works of other artists and forming intertextual relationships. The meaning and the transmitted message and ideology of the final product can't be thought of as separate from works with which it has formed an association. In art education, various activities can be developed based on intertextuality, an area of interest common to both visual culture and semiotics. For instance, an advert created by using extracts borrowed from other artworks can be interpreted using the semiotic method. This way, 
its manifest and connotative meanings, the potential ideologies and implications present in the deep plane can be uncovered. This will be followed by the application of the semiotic method to the artwork, which now has an intertextual relationship with the advert. The meanings revealed in these two works may prompt new questions: What are the intertextual relationships between the two works? What kinds of texts were associated? What new meanings did the intertextual relationship add to the original? What are the linguistic differences between the two works? Discussion might centre around why this particular artwork was used in the making of the advert by theorizing on the meaning of the artwork as deduced through the semiotic method. How does the mass transmission of this work - via commercialization - alter our perception and opinion of it? A comparative study can be carried out based on the ideological messages transmitted to us on the advert's depth plane and the ideological messages uncovered in the artwork. This way, questions can be formulated in regard to meanings and messages deduced through semiotic analysis, encouraging students to engage with and criticize visual culture and the problems of contemporary art.

The object of semiotic analysis isn't criticism. The object is to reveal, using objective methods, the meaning, its manufacture and modes of articulation. The primary intent of semiotics is to explain the conditions surrounding the perception and production of meaning within a conceptual framework (Kiran, 2010). In reading visual culture, once interpretations have been formulated in regard to the object undergoing semiotic analysis, it is then possible to conduct critical studies of meanings that have been unearthed through different approaches and methods. The works of the film theorist, Metz, are a prime example. Through semiotic analysis and psychoanalytical methods, Metz was able to carry out a series of studies on cinematic meaning making (Buckland, 2000). Furthermore, he also carried out psychoanalytical studies on meanings he had derived through the semiotic method. Once the objects of popular culture (e.g. adverts, films, paintings) have been analysed through the semiotic method, the findings can be used in other future studies. The semiotic method can be used to conduct comparative studies in art education, art criticism courses and visual cultural analyses.

The advantage of the semiotic method is that it is applicable to any object (e.g. works of art, adverts, film) that transmits meaning. In this regard it is more closely related to polymorphism than to the elements of visual culture that are its central focus. Polymorphism is concerned with the signifier plane that comprises the sign and its formal aspect. In visual culture studies, analyses and various studies can be carried out- using the semiotic method - based on constructs made up of different signifiers having multiple forms. For instance, after analysing a biographical film about an artist using the semiotic method, one may also proceed to interpret a work belonging to the 
artist using the semiotic method. This could be followed by comparisons and critical studies.

Previously, we defined visual culture as the pedagogy of the image, which concerns itself with how we see things, how we assign meaning to them, and the significance artificial images have for the individual, society and the world at large. In visual cultural readings, it is possible to systematically expose the hidden values and ideologies transmitted to us using progressive semiotic methods. All kinds of studies may be carried out based on these derived meanings - including critical studies.

\section{CONCLUSION}

As an integral part of visual culture, art provides visual culture with usable materials while it becomes influenced by visual culture. When artists make use of other visual cultural media during their creative processes, this can blur the lines between what is art and what is not. Each of these developments has an impact on art education and art criticism. In the field of art education in particular, there is a need to assess and critique the products of visual culture by further developing critical capacity and visual literacy. In keeping with these demands, the quantitative increase in studies on visual culture studies in the field of art education are significant. Previously, we defined visual culture as the 'pedagogy of the image', which concerns itself with how we see things, how we assign meaning to them, and the significance artificial images have for the individual, society and the world at large. It was surmised that, due to their fields of interest, i.e. meaning, signification and the manufacture of meaning, the analytical methods suggested by semiotics might be more effectively used in cultural critiques of visual culture in art education. At this point it was stated that the semiotic method might be used in art education and visual cultural studies to discern the meaning of messages transmitted to us through images. Images, markings, symbols, the entire output of the visual culture and works of art are all comprised of signs and are the building blocks of visual culture. They fall within semiotics' field of study.

After providing an explanation of visual culture and semiotics, the study proceeded to identify the core topics of visual culture studies in art education and utilizing semiotic method on them. These core topics are: ideology and power, representation, perception, intertextuality and polymorphism.

The visual images that makeup visual culture put competing social discourses into circulation are instrumental in their reproduction. The fact that visual images and signs are fabricated, with meaning being forged in culture, underlines the importance of being critical and resilient in the visual realm. By interpreting the messages 
transmitted through visual cultural products, it is possible to systematically expose the ideologies they entail. Critical studies may be carried out based on the meanings that are identified. If one considers the purpose of art education, which aims to train individuals who are in touch with their culture and critical of art and their environment, the benefits of visual cultural readings based on semiotics in increasing students' awareness becomes obvious. Moreover, questions asked in relation to works of art and visual culture, which are now less distinct due to the tools they use and their role in the visual culture, may encourage students to tackle the problems currently surrounding the art world.

The role of visual cultural studies does not solely consist of the meanings transmitted by visual imagery and their critique. It is also concerned with the question of how different visuals may be produced. As students engage with the semiotic interpretation of every imaginable visual cultural product, they also comprehend the linguistic differences present between them. Indeed, semiotics is a scientific device for developing theoretical models. Its aim is to study and explain the ways in which meanings are articulated and produced while also providing insight into their production process (Rifat, 1992). The meanings transmitted through the signs of visual culture - as deduced by semiotic methods - can also provide clues into how messages are configured. This process, which continues on a theoretical basis, will also have an impact on the students' practical engagement. Through visual cultural readings and comprehension of the signs that make up visual culture, it is possible to be critical of all approaches which popularize the values of the dominant culture while destroying others, condemning them to the role of the 'other' and making art just another commodity. Thus, as the field of art education turns out individuals with greater awareness, it may also be possible, through struggles waged in the visual realm, to expect a society that is freer, more socially just and democratic. 


\section{REFERENCES}

Akerson, Fatma Erkman. Göstergebilime Giriş [Introduction to Semiotics]. Istanbul:

Multilingual, 2005.

Alfaro, Martinez ve Jesus Maria. "Intertextuality: Origins and Development of the Concept".

Atlantis 18. 1 (1996): 268-285.

Artun, Ali. Çağdaş Sanatın Örgütlenmesi: Estetik Modernizmin Tasfiyesi [Organization of

Contemporary Art, the end of Aesthetic Modernism]. Istanbul: İletişim Yayıncılık, 2011.

Aslan, Umut Tümay. "Görsel Olanı Okumak: Eleştirel Görsel Okur-Yazarlık". [Reading the visual, critical visual literacy], İletişim Araştırmaları 1.1 (2003): 39-65.

Barnard, Malcolm. Sanat, Tasarım ve Görsel Kültür [Art, Desıgn and Visual Culture: An Introduction]. Istanbul: Ütopya Yayınevi, 2010.

Buckland, Warren. The Cognitive Semiotics of Film. United Kingdom: Cambridge University Press, 2000.

Danto, Arthur. After the End of Art : Contemporary Art and the Pale of History. New Jersey: Princeton University Press, 1997.

Duncum, Paul. "The Theories and Practices of Visual Culture in Art Education, Arts Education Policy Review". 105. 2 (2003): 19-25.

Duncum, Paul "Seven Principles for Visual Culture Education”. Art Education 63.1 (2010): 610.

Grunwald Declaration on Media Education. (22 January 1982) 6 May

2014. http://www.unesco.org/education/pdf/MEDIA_E.PDF

Jameson, Fredric. Postmodernizm ya da Geç Kapitalizmin Kültürel Mantığı

[Postmodernism or the Cultural Logic of Late Capitalism]. Istanbul: Yap1 Kredi

Yayınlar1, 1994. 
Kappelman, Todd. Marshall McLuhan: "The Medium is the Message" Probe Ministries International, (2001) 12 Eylül 2015. http://www.leaderu.com/orgs/probe/docs/mcluhan.html

Kellner, Douglas. "Critical Perspectives on Visual Imagery in Media and Cyberculture”. Journal of Visual Literacy 22.1 (2002): 81-90.

Kıran, Ayşe. Eziler. "Çağdaş Bir Düşünme Biçimi Olarak Göstergebilim” [Semiotics as a contemporary way of thinking], Dilbilim 2.2 (2010): 1-18.

Leppert, Richard, Sanatta Anlamın Görüntüsü: İmgelerin Toplumsal İşlevi [The Images of Meaning in Art: The Social Function of the Images]. Çev. Türkmen İsmail. Istanbul: Ayrıntı Yayınları, 2009.

Mirzoeff, Nicholas. The Visual Culture Reader. Yyy: Psychology Press, 2002.

Mumby, Dennis. K. "Ideology, the Social Construction of Meaning: A Communication Perspective". Communication Quarterly 37.4 (1989): 291-304.

Prensky, M. "Digital Natives, Digital Immigrants". On the Horizon 9.5 (2001): 1-6.

Rifat, Mehmet. Göstergebilimin Abc'si [Fundamentals of Semiotics]. Istanbul: Simavi Yayınları, 1992.

Rifat, Mehmet. and Rifat Sema. XX. Yüzyılda Dilbilim ve Göstergebilim Kuramları [XX. Century Theories of Linguistics and Semiotics]. Istanbul: Om Yayınevi, 2000.

Rifat, Mehmet. XX. Yüzyılda Dilbilim ve Göstergebilim Kuramları, 1. Tarihçe ve Eleştirel Düşünceler [XX. Century Theories of Linguistics and Semiotics, 1. History and Critical Thinking]. Istanbul: Yapı Kredi Yayınları, 2008.

Rogoff, Irit. "Studying Visual Culture". In Nicholas Mirzoeff [Ed.] The Visual Culture Reader. London: Routledge, (1998): 24-36.

Sezal, İhsan. Sosyolojiye Giriş [Introduction to Sociology]. Ankara: Martı Yayınları, 2002.

Tavin, Kevin. “Engaging Visuality: Developing a University Course on Visual Culture”. The International Journal of the Arts in Society 4.3 (2009): 115-124. 
Thoman, Elizabeth ve Jolls, Tessa. 21. Yüzyıl Okuryazarlığı: Medya Okuryazarlığına Genel Bir Bakış ve Sınıf İçi Etkinlikler [21st Century Literacy: An Overview of Media Literacy and Classroom Activities]. Çev. Cevat Elma ve Alper Kesten. Ankara: Ekinoks Yayınevi, 2008.

Trier, James. Guy Debord's “The Society of the Spectacle”. Journal of Adolecent \& Adult Literacy 51.1 (2007): 68-73.

Tunalı, İsmail. Estetik [Aesthetic]. Istanbul: Remzi Kitabevi, 2004. 